УДК 004

\title{
ТЕХНОЛОГІЇ МОДЕЛЮВАННЯ УПРАВЛІНСЬКИХ ІНФОРМАЦІИНИХ СИСТЕМ В СИСТЕМІ МЕНЕДЖМЕНТУ ПІДПРИЄМСТВА
}

\section{TECHNOLOGIES FOR MODELING MANAGEMENT INFORMATION SYSTEMS IN THE MANAGEMENT SYSTEM OF THE ENTERPRISE}

\author{
Терещенко Лариса Олександрівна \\ кандидат економічних наук, профресор, \\ Український гуманітарний інститут \\ ORCID: https://orcid.org/0000-0003-0680-5259 \\ Tereshchenko Larisa \\ Ukrainian Institute of Arts and Sciences
}

\begin{abstract}
Розвиток інформаційних систем, як елемент управління, тісно пов'язаний зі змінами, які відбуваються у сорерах їх використання. У статті розглянуто процес управління який характеризується багатофрункціональністю, яка виявляється в особливостях реалізації основних фрункцій управління. Досліджено підходи щодо моделювання процесу управління та його складових з використанням інфрормаційних систем і технологій, вплив цих систем на прийняття управлінських рішень в системі менеджменту підприємства, і усього різноманіття методів дослідження систем управління компаніями. Проаналізовано саме моделювання як інструмент дослідження, що застосовується за наявності фрормальних кількісних даних та інформації. Надано пропозиції щодо етапів реорганізації управлінських інфрормаційних систем в системі обліково-аналітичного забезпечення менеджменту підприємства.
\end{abstract}

Ключові слова: система управління, управлінська інформаційна система, ІТ-технології, фрункцій управління, модель системи управління, предметна галузь, технології моделювання.

Развитие информационных систем, как элемент управлени, тесно связан с изменениями, которые происходят в сорерах их использования.В статье рассмотрен процесс управления который характеризуется многофрунциональностью, которая оказывается в особенностях реализации основных функций управления. Исследованы подходы относительно моделирования автоматизации управленческого процесса и его составных в системе менеджмента предприятия, сущность основных понятий, влияние этих систем на принятие управленческих решений, Со всего многообразия методов исследования систем управления компаниями проанализировано само моделирования как инструмент исследования, которое применяется при наличии фрормальных количественных данных и инорормации. Даны предложения относительно этапов реорганизации управленческих информационных систем в системе учетно-аналитического обеспечения менеджмента предприятия.

Ключевые слова: система управления, управленческая информационная система, IT-Технологии, срункции управления, модель системы управления, предметная область, технологии моделирования.

The development of information systems, as anelement of control, is closely related to the changes taking place in the areas of their use. A modern enterprise management system is impossible to imagine without a management information system. The information system generates reliable and complete information about the property status, liabilities and business operations of the object of management. This makes it possible to: increase the degree of validity of management decisions; ensure the timeliness of decisions; seek to increase the efficiency of management through the timely provision of the necessary information; to coordinate the decisions made at different levels of management, due to the awareness of management staff about the current state of the object; provide rapid response and management decisions. The article considers the management process which is characterized by multifunctionality, This is manifested in the peculiarities of the implementation of basic management functions. As management is targeted, the management information system is designed to provide decision support. Approaches to modeling the management process and its components using information systems and technologies are studied. The influence of these systems on management decisions in the management system of the enterprise 
has been analyzed. From all the variety of research methods of company management systems, modeling itself is analyzed as a research tool used in the presence of formal quantitative data and information. Proposals on the stages of reorganization of management information systems in the system of accounting and analytical support of enterprise management are given. Modern management information systems are able to process information for all management functions and transmit it to all levels of government. As for the information modeling of the subject area, it is a part of the real world, which is represented, reflected and used in the MIS. The subject area, which is represented by various forms of finite information, is called the information model. And most important factor is that a modern management information system must meet all the innovations in the theory and practice of management.

Keywords: control systems, management information system, model of control system, IT-technologies, information modeling, subject branch of modeling technology.

Постановка проблеми. Досягнення значних результатів в економіці, завоювання місця повноправного партнера в економічній системі в значній мірі залежить від масштабів використання управлінських інфрормаційних систем і IT-технологій, а також роль технологій у підвищенні есрективності в системі менеджменту підприємства.

Впровадження в управлінську діяльність дослідницького підходу який базується на застосуванні інтегрованих інформаційних систем та інорормаційних технологій для автоматизації управлінських процесів підприємства, їхнього моделювання, прогнозування, аналізу, контролю.

Аналіз досліджень і публікацій. Значний внесок у дослідження технологій моделювання управлінських інформаційних систем менеджменту зробили такі зарубіжні та вітчизняні вчені: Ансофрф И., Адамадзіев К.Р., Архипова Н.И., Ахтирченко К.В., Баронов В.В., Вендов В.В., Кульба А.М., Маклаков С.В., Ойхман Е.Г., Попов Э.В., Рубцов С., Титоренко Г.А., Трубіліна И.Т.

В умовах розвитку сучасного інфрормаційного простору, питання використання інсрормаційних систем в управлінській діяльності залишаються актуальними.

Формулювання цілей статті. Дослідити технології інфрормаційного моделювання предметної сорери, яка представляється, відображається і використовується в управлінській інфрормаційній системі менеджмету підприємства.

Виклад основних матеріалів дослідження. В Україні склалася нова економічна система, основою якої є ринкові відносини де насамперед кількісних змін зазнають важелі управління. І одним із елементів управління економікою країни $€$ розвиток інформатизації процесів управління. Ефеективного функціонування можна досягти за умови її глибокої модернізації, одним 3 найвищих складників якої $€$ використання сучасних досягнень у галузі інфрормаційних технологій, що забезпе- чують повноту, своєчасність інфрормаційного відображення керованих процесів, можливість їх моделювання, аналізу, прогнозування на всіх рівнях ієрархічної структури [6, с. 6]. Потреба у використанні поняття «система» виникла для об'єктів різної фрізичної природи у глибокій стародавності: ще Аристотель звернув увагу на те, що ціле (тобто система) не зводиться до суми частин його утворюючих. Поняття «система» широко використовується в різних галузях знань, але особливе значення воно набуло в управлінні. Це визнано тим, що значно ускладнилося управління сучасними підприємствами і економікою країни в цілому.

Поняття «система» що вживалося раніше в повсякденному значенні, перетворилося в спеціальну загальнонаукову категорію, так з'явилося поняття «система управління». В науково-технічній літературі часто використовують термін «система», «система управління», «автоматизована система управління» [6, с. 9].

Навіть відносно невеликі компанії є складними системами, оскільки володіють непростою ієрархічною структурою 3 численними взаємозв'язками між об'єктом управління i управлінською системою. Процес управління характеризується багатофрункціональністю, яка виявляється в особливостях реалізації основних функцій управління: прогнозування, планування, контролю, обліку, аналізу і регулювання. Компанія, як система, в умовах зміни середовища зберігає властивість цілісності і володіє такою характеристикою як емерджентність. В економічних системах управління будується на основі економіко-організаційних моделей, так як система, що управляє, повинна мати уявлення про образ об'єкта. І оскільки модель в деякій формі відображає процеси, що реально протікають, і виникає проблема їі адекватності. Модель завжди відрізняється деталями від самого об'єкта, але обов'язково має з ним щось загальне. Порівняно простими є фрункціональні моделі, що описують залежність виходу від входу, складнішими - структурні моделі, що включа- 
ють і функціональний, і структурний аспекти. Моделі, як і системи, можуть бути імовірнісними і детермінованими. Управлінська інфрормаційна система (УІС) $€$ детермінованою моделлю системи управління, відображаючи процеси, що відбуваються, через призму своїх технологій. Велика кількість і різноманітність економічних систем породжують велику різноманітність УІС, адже, відображаючи систему управління, УІС таким чином убирають в себе особливості структури управління, схеми декомпозиції управлінських цілей, наочних технологій [6, с. 125].

Що стосується інформаційного моделювання предметної галузі - це частина реального світу (у нашому випадку - частина економічної системи), яка репрезентується, відображається і використовується в УІС.

Предметна галузь, що відображається за допомогою різних фрорм кінцевої інфрормації, називається інфрормаційною моделлю.

Модель - це об'єкт, який в певних завданнях може замінювати оригінал.

Наведемо етапи інфрормаційного моделювання під час створення економічної інфрормаційної системи:

$\{П Г\}-->\{$ описова КМ $\}-->\{$ ЛМ, МM $-->\{$ АM, П $\},(1)$

де ПГ - предметна галузь; КМ - концептуальна модель; ЛМ - логічна модель; MM - математична модель; АМ - алгоритмічна модель; П - програма.

Концептуальна модель (КМ) - це модель, яка відображає знання фрахівця в певній галузі про її об'єкти та їхні взаємозв'язки, процеси і результати діяльності.

Логічна модель (ЛМ) - ПЗ за допомогою інструментарію аналізу і проектування IC.

математична модель (МM) - це записані за допомогою математичного апарата залежності між параметрами (показниками) модельованих процесів.

Зручним засобом інорормаційного моделювання предметної галузі $€$ апарат показників.

3 одного боку показники $€$ основними (інорормаційними) одиницями документів компанії, між ними встановлюються математичні взаємозв'язки. Від них просто переходити до таблиць і баз даних (БД).

Під час подання й аналізу економічної інфрормації, виділяють наступні економічні показники: процесу виробництва; виконавця; показники завдання; об'єкта управління; суб'єкта управління.

Моделі для подання знань в УІС:
- продукційна модель дозволяє за рахунок правил одержати фракти, які на момент запису правил були невідомі;

- мережна модель - в ній відтворюються об'єкти, відносини між ними, події, взаємозв'язки, процеси за допомогою апаратно-математичних мереж;

- ситуативна модель (БС) заснована на базах знань (БЗ)

$$
\text { БЗ }=\langle\text { БС, БР }\rangle
$$

де БЗ - база знань, БС- база ситуацій, БР база рішень.

База ситуацій безпосередньо пов'язана 3 базою рішень БС<=>БР - кожній ситуації відповідає своє рішення [6, с. 126].

Ситуація - деякий структурований опис стану системи управління, зовнішнього середовища, переваг суб'єкта.

Узагальнена схема виведення ситуативної моделі:

- привласнення значень поточної ситуації;

- розпізнавання поточної ситуації і пошук в базі знань ситуації - прикладу, найбільш схожого з поточною ситуацією;

- вибір рішення, пов'язаного зі знайденим прикладом.

Структура ситуативної моделі, як і інших, але у меншою мірою, часто буває об'єктноорієнтованою. Особливість об'єктноорієнтованої моделі - класи ситуацій організовуються в ієрархічну структуру засобами об'єктно-орієнтованого програмування (ООП) [6, c. 126].

В умовах реформування галузі ключовим чинником успішного розвитку стає ефрективне управління змінами (Change Management). Процесний підхід до аналізу і моделювання процесів бізнесу і надалі - до проектування інформаційних систем управління виробництвом - дозволить оперативно змінювати і допрацьовувати технології, без зупинки виробництва модернізовувати інформаційну систему компанії [2].

3 усього різноманіття методів дослідження систем управління компаніями слід виділити саме моделювання як інструмент дослідження, що застосовується за наявності фрормальних кількісних даних та інформації.

Процесні потокові моделі описують процеси в ході послідовного перетворення матеріальних та інорормаційних потоків. У них розкривається логіка взаємодії всіх учасників процесу. За допомогою інструментальних CASE-засобів проектування й аналізу процесів бізнесу можна: 
- зафріксувати поточні процеси - вони добре підходять для графрічного представлення наявних виробничих процесів, дозволяють знайти проблемні питання і критичні моменти, зрозуміти складні процеси і допомагають створити комплексну модель виробництва;

- визначити нові потреби бізнесу - сфрормувати ідеї і знайти кращі способи діяльності компанії;

- розділити і оцінити варіанти з використанням різних методів і засобів оцінки для вибору найвигіднішого зі способів здійснення поставлених цілей [6, с. 127].

CASE-засоби використовуються для специсрікації процесів бізнесу в системах управління виробництвом 3 метою їх реорганізації та автоматизації, в розробці апаратного і програмного забезпечення інтегрованих систем, що інфрормаційно управляють, і в багатьох інших галузях виробництва [1].

Будь-яка інфрормаційна система має тенденцію до постійного розвитку. Відповідно, для того, щоб створити управлінську інорормаційну систему, спочатку необхідно мати аналогічну модель інфрормаційних потоків і взаємодій.

Перша модель компанії, яку необхідно побудувати - «as is» («як є»). На цьому етапі необхідно відобразити повну і якомога реальнішу картину бізнес-процесів компанії. I тут слід скористатися послугами незалежних експертів, працівників компанії, відповідальних за прийняття рішення [6, с. 100]. Наступна модель - «to be» («як повинно бути»). Взагалі, процес моделювання даної моделі - аналогічний моделі «як є». Проте слід зробити провести дослідження, що можна поліпшити, виходячи 3 критеріїв повторюваності, дублювання, надмірності, перенасиченості, ускладнення. Ознайомити експертів з цими матеріалами для ухвалення рішення, побудувати нову модель, провести аналіз [6, с. 101].

Модель «to be» («як повинно бути») є процес постійного вдосконалення технологічних процесів.

Власне, перехід від моделі «аs is» («як є») до моделі «to be» («як повинно бути») і є суть реінжинірингу. Основне завдання реінжинірингу - підвищення ефрективності управління, інорормативності, прозорості в прийнятті управлінських рішень.

Під час створення моделі «як є» в процесі «зворотного реінжинірингу» виконуються роботи, пов'язані з аналізом інсрормаційних потоків, що є в компаніях.
Методи розвиваються як досвід виділення найкращої практики в специфічній області інтелектуальної або фрізичної дії. Методологія має, принаймні, два загальні шляхи розвитку.

По-перше, відносно класу подібних методів. Згідно цьому можна, наприклад, розглянути метод як посилання на функціональну методологію моделювання IDEFO.

По-друге, методологія використовується, щоб проаналізувати колекцію методів та інструментальних засобів, використання яких дозволить описати управління процесом [6, с. 101].

Методологія IDEFO - це сукупність робіт, кожна з яких оперує з деяким набором даних. Графрічно вона виглядає як перелік ієрархічно впорядкованих і взаємозв'язаних діаграм, на яких робота зображується у вигляді прямокутників, а дані - як стрілки Універсальна IDEF0-модель бізнес-процесів компанії представлено на рис. 1 [6, с. 129].

Під час розробки загальної моделі IDEFO використовуються певні концепції, запозичені 3 моделі взаємодії відкритих систем, методичних матеріалів асоціацій документального електрозв'язку і телекомунікаційного співтовариства:

- на вході бізнес-процесу надходять з виходів ресурси контрагентів, які перетворяться в інші види ресурсів;

- всі бізнес-процеси в компанії об'єднані одним завданням - наданням послуг один одному на основі аналізу запитів про постачання послуг. Зокрема, послугою може бути виготовлення і постачання продукту;

- надання послуг один одному бізнес-процесу здійснюють згідно з єдиною процедурою [5].

При проектуванні УІС на першому етапі проектування встановлюються фрункції управління, а саме: прогнозування, планування, облік. контроль, аналіз і регулювання і зміст робіт по їх виконанню. згідно рівнів управління (вищий, середній, оперативний).

Прогнозування - фрункція, за допомогою якої здійснюється фрормування та обґрунтування наукових передумов перспективи розвитку об'єкта управління, можливих змін його стану до певного моменту часу в майбутньому [4].

Планування - функція, за допомогою якої в ідеальній фрормі реалізується мета управління.

Облік - фрункція, направлена на отримання інсрормації про роботу компанії [6, с. 13].

Контроль - зіставлення фрактичних показників із плановими і нормативними, визначення відхилень, що виходять за межі допустимих значень. Виконується на всіх трьох рівнях управління. 


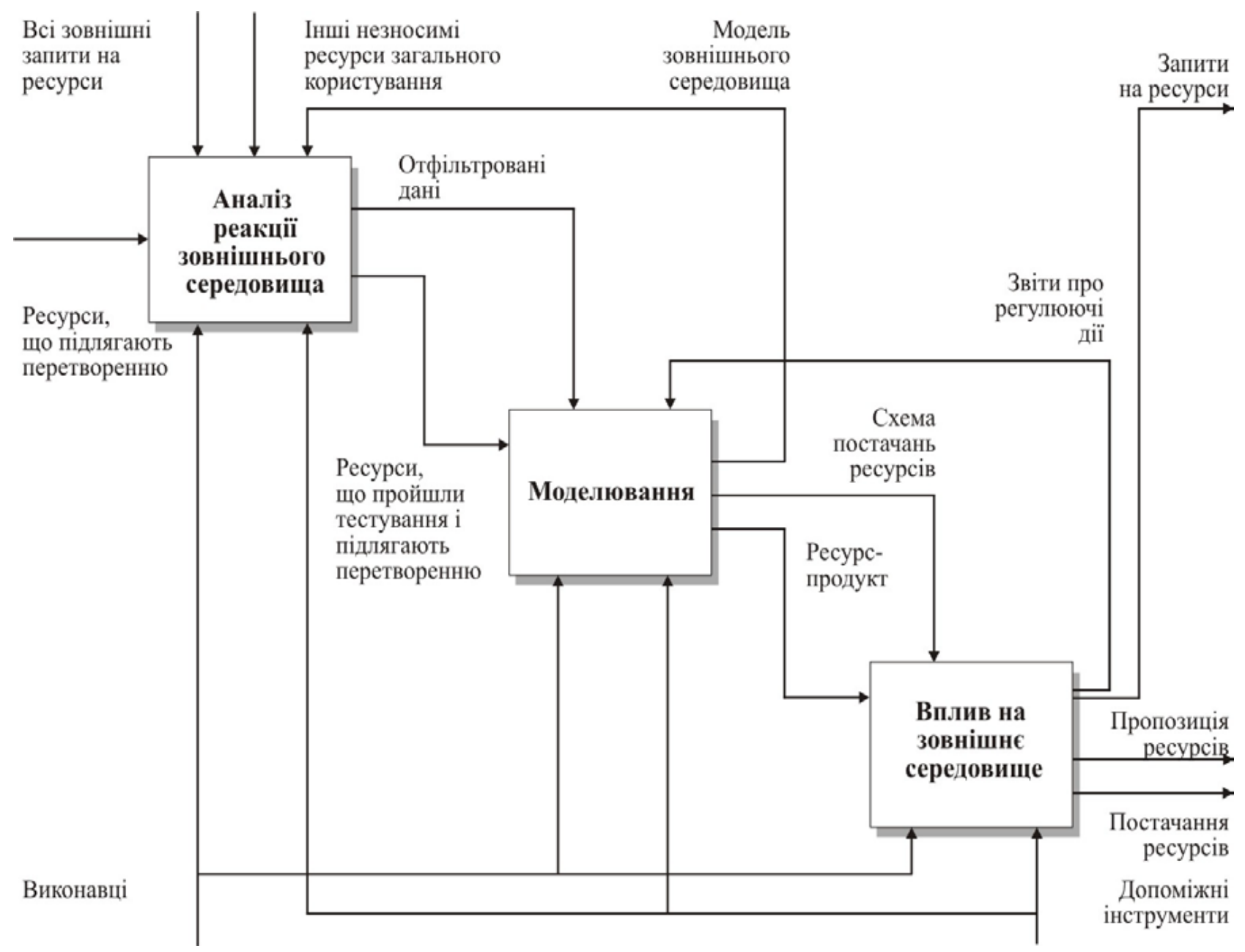

Рис. 1. Універсальна IDEF0-модель бізнес-процесів компанії

Аналіз і регулювання - установлення причин відхилень, виявлення резервів, знаходження шляхів виправлення ситуації, що утворилася, і прийняття рішення щодо виправлення ситуації. Виконується на середньому та вищому рівнях управління [6, с. 14].

Управлінський апарат має три рівня управління: вищий, середній і оперативний рівні де в процесі управління приймаються стратегічні, тактичні та оперативні рішення.

Вищий рівень (вище керівництво) визначає цілі управління, зовнішню політику, матеріальні, фрінансові і трудові ресурси, розробляє довготермінові плани і стратегію їх виконання. На середньому рівні основна увага зосереджена на складанні тактичних планів, контролі за їх виконанням та розробці управлінських директив для виведення компанії на запланований рівень. На оперативному рівні відбувається реалізація планів і складаються звіти про хід їх виконання [6, с. 12].

Сучасні УІС здатні обробляти інфрормацію за всіма фрункціями управління і передавати ії на всі рівні управління [6, с. 14].
У результаті побудованих моделей щодо кожної фрункції можна знайти її виконавців - підрозділ або співробітника, що дає можливість виявити прогалини як у виконанні функцій, так і в завантаженості працівників [6, c. 132].

Висновки. Зі всього різноманіття методів дослідження систем управління компаніями слід виділити саме моделювання як інструмент 1 реінжиніринг) на основі аналізу наявних інформаційних потоків;

- створення срункціональних моделей «as is» («як є») для підрозділів, що забезпечують інорормаційну підтримку компанії;

- розробка цілей і стратегії розвитку інфрормаційної системи управління компанією з урахуванням її розвитку;

- створення фрункціональних моделей «to be» («як повинно бути»)для основних бізнеспроцесів компанії;

- побудова моделі інфрормаційної інфраструктури компанії;

- побудова моделі нової організаційної структури; 
- створення імітаційних процесних моделей виробництва і на їх основі побудова моделей управління потоками робіт;

- створення системи документообігу на основі моделей потоків даних і управління якістю;

- реорганізація виробництва та інфрормаційної системи управління.

За допомогою аналізу інформаційних потоків можна визначити найбільш значущі для прийняття управлінських рішень дані, розробити перспективну архітектуру інформаційної системи [3]. Результат аналізу інформаційних потоків і фрункцій управління в компанії є основою побудови фуннкціональної моделі. Ці моделі будуються для кожного рівня управління.

А за рахунок реалізації конкретної виробничої моделі можна одержати експлуатаційні переваги і тим самим зменшити сукупну вартість володіння інфрраструктурою.

Таким чином, упровадження управлінських інформаційних систем і ІТ-технологій $\epsilon$ обов'язковою умовою діяльності сучасного підприємства, що сприятиме прийняттю обґрунтованих стратегічних управлінських рішень.

\section{СПИСОК ВИКОРИСТАНИХ ДЖЕРЕЛ:}

1. Маклаков С.B. BPwin и ERrwin. CASE-средства разработки информационных систем. Москва : ДИАЛОГ-МИФИ, 2000. 256 с.

2. Организационное управление : учеб. пособие для вузов / Под ред. Н.И. Архиповой, В.В. Кульба и др. Москва : Изд-во «ПРИОР», 1998. 448 с.

3. Ойхман Е.Г., Попов Э.В. Реинжиниринг бизнеса: реинжиниринг организации и инсрормационных технологий. Москва : Финансы и статистика, 1997. 150 с.

4. Пономаренко В.С., Бутова Р.К., Журавльова І.В., Назарова Г.Н., Павленко Л.А. Інформаційні системи і технології в економіці : Посібник для студентів вищих навч. закладів. Київ : Академія, 2002. 544 с.

5. Рубцов С. Опыт использования стандарта. URL: https://blog.iteam.ru/opyt-ispolzovaniya-standarta-idefo/

6. Терещенко Л.О., Гужко С., Шайкан А.В. Управлінські інфрормаційні системи : підручник. Київ, 2008. 485 с.

\section{REFERENCES:}

1. Maklakov S.V. (2000) BPwin and ERrwin. CASE-tools for the development of information systems. Moscow: DIALOG-MEPhl, $256 \mathrm{p}$.

2. Organizational management: Textbook. textbook for universities (1998) / Ed. N.I. Arkhipova, V.V. Kulba et al. Moscow: PRIOR Publishing House, $448 \mathrm{p}$.

3. Oikhman E.G., Popov E.V. (1997) Business reengineering: organization and information technology reengineering. Moscow: Finance and statistics, $150 \mathrm{p}$.

4. Ponomarenko V.S., Butova R.K., Zhuravlyova I.V., Nazarova G.N., Pavlenko L.A. (2002) Information systems and technologies in economics: A guide for students of higher education. institutions. Kyiv: Akademia, $544 \mathrm{p}$.

5. Rubtsov S. Experience of using standard. URL: https://blog.iteam.ru/opyt-ispolzovaniya-standarta-idef0/

6. Tereshchenko L.O., Guzhko S., Shaikan A.V. (2008) Management information systems: pidruchnik. Kyiv, 485 p. 